\title{
LASER SCANNING TECHNOLOGY FOR THE HYPOGEAN SURVEY: THE CASE OF SANTA BARBARA KARST SYSTEM (SARDINIA, ITALY)
}

\author{
UPORABA TEHNOLOGIJE LASERSKEGA SKENIRANJA V IZMERI \\ JAM: PRIMER SISTEME SANTA BARBARA (SARDINIJA, ITALIJA)
}

\author{
Erminio Paolo CANEVESE ${ }^{1}$, Paolo FORTI ${ }^{2}$, Angelo NASEDDU ${ }^{3}$, \\ Luciano OTTELLI ${ }^{4} \&$ Roberta TEDESCHI ${ }^{5}$
}

\begin{abstract}
UDC 528.8.042:551.44(450.88)

Erminio Paolo Canevese, Paolo Forti, Angelo Naseddu, Luciano Ottelli \& Roberta Tedeschi: Laser Scanning Technology for the Hypogean Survey: the case of Santa Barbara Karst System (Sardinia, Italy)

The morphological knowledge of the territory, both in its surface and subterranean aspects, is the main premise to all decision-making procedures as well as all planning and management activities. Knowledge takes shape into reliable precise and complete thematic cartography and databases, which are necessary for anybody dealing with underground contexts: speleologists, scientists, public administrations, managing authorities etc.

Surveys in caves are normally carried out with traditional techniques and instruments, which are essential for a first representation but not enough for a pragmatic effective topographic approach. Laser scanning technique can be an alternative to the traditional systems. Laser scanning quickly acquires the shape of cavities as "point clouds" ( $\mathrm{x}, \mathrm{y}, \mathrm{z}$ coordinates and colour values) and produces a high precision database of the surveyed object. Laser scanning technology is therefore a feasible way to document caves in a precise exhaustive way, limiting risks relating to lack and/or inadequacy of data.

The present paper explains the laser scanning survey carried out in San Giovanni mine near Iglesias (Sardinia, Italy), particularly in Santa Barbara and Santa Barbara 2 caves, the data post-processing and three-dimensional modelling of "point
\end{abstract}

\begin{abstract}
Izvleček
UDK 528.8.042:551.44(450.88)

Erminio Paolo Canevese, Paolo Forti, Angelo Naseddu, Luciano Ottelli \& Roberta Tedeschi: Uporaba tehnologije laserskega skeniranja v izmeri jam: primer sisteme Santa Barbara (Sardinija, Italija)

Dobro poznavanje podzemne in površinske morfologije je pomembno za upravljanje in načrtovanje določenega območja. Izmera jam največkrat poteka $\mathrm{z}$ uporabo standardnih instrumentov, ki so bistveni za osnovno predstavitev podzemne morfologije, za praktično uporabo pa so ti podatki velikokrat preskopi. Alternativa tradicionalnemu pristopu je lasersko skeniranje, ki podzemni prostor zajame v obliki točkovnega oblaka (vrednosti x,y,z koordinat in barve). Tako dobimo bazo podatkov merjenega objekta $\mathrm{z}$ visoko ločljivostjo. Lasersko skeniranje ponuja možnost natančne izmere podzemnega prostora brez tveganja povezanega $\mathrm{z}$ nezadostno gostoto podatkov. $\mathrm{V}$ članku opišemo izmero jam $\mathrm{z}$ metodo laserskega skeniranja v rudniku San Giovanni blizu mesta Iglesias na Sardiniji. Na primeru jam Santa Barbara in Santa Barbara 2 pokažemo zajem in obdelavo podatkov ter uporabo dobljenega digitalnega modela. Predstavimo prednosti in potenciale tehnologije laserskega skeniranja $\mathrm{v}$ primerjavi s tradicionalnimi metodami izmere jamskih objektov.

Ključne besede: lasersko skeniranje, rudniške jame, Sardinija, izmera, topografija, tri dimenzionalno modeliranje, Sardinija, Italija.
\end{abstract}

\footnotetext{
${ }^{1}$ Erminio Paolo Canevese - Virtualgeo s.r.l., Viale Trento 105/D, 33077 Sacile (PN), Italy, e-mail: erminio.canevese@virtualgeo..it ${ }^{2}$ Paolo Forti - Istituto Italiano di Speleologia, Dipartimento di Scienze della Terra e Geologico-Ambientali, Università di Bologna Alma Mater Studiorum, Via Zamboni 67, 40126 Bologna \& La Venta Exploring Team, Italy, e-mail: paolo.forti@unibo.it

${ }^{3}$ Angelo Naseddu - Speleo Club Domusnovas, Via Baracca 3, 09015 Domusnovas (CI) \& Federazione Speleologica Sarda Regione Miniera San Giovanni, 09016 Iglesias (CI), Italy, e-mail: angelonaseddu@alice.it

${ }^{4}$ Luciano Ottelli - Parco Geominerario Storico Ambientale della Sardegna, Via Monteverdi 16, 09016 Iglesias (CI), Italy, e-mail: direttore@parcogeominerario.sardegna.it

${ }^{5}$ Roberta Tedeschi, Virtualgeo s.r.l., Viale Trento 105/D, 33077 Sacile (PN) \& La Venta Exploring Team, Italy, e-mail: roberta.tedeschi@virtualgeo.it
}

Received/Prejeto: 9.9.2010 
clouds" (operations performed with a dedicated software), and the use of the obtained digital model. Moreover, the paper describes the advantages of laser scanning for the hypogean survey in comparison to traditional methods and the future potentialities of a broad application of laser scanning instruments in caves.

Keywords: laser scanner, mine caves, Sardinia, survey, topography, three-dimensional modelling.

\section{INTRODUCTION}

Santa Barbara cave is one of the most famous mine caves in the world, hosting the most beautiful barite crystals (Fig. 1) developed within a natural cavity (Forti \& Perna 1982). The cave was accidentally discovered in 1952 while digging a shaft within San Giovanni mine, close to Iglesias (Fig. 2). In San Giovanni mine, which is in the middle of the Iglesiente mining district in South-Western Sardinia (Italy), a deposit of poly-sulphides was exploited for over 2,000 years.

The cave was immediately closed after its discovery to defend its extraordinary speleothems but sometimes tourists and scientists were allowed to enter. After the mining activity ended, since 2001 the whole Iglesiente mining area belongs to the Geo-mining Historical and Environmental Park of Sardinia, which was included in

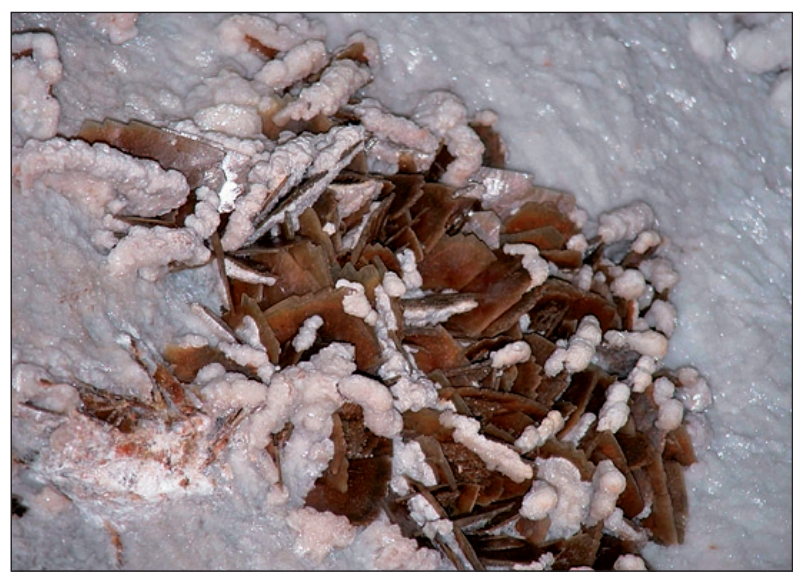

Fig. 1: A barite crystal of Santa Barbara cave.

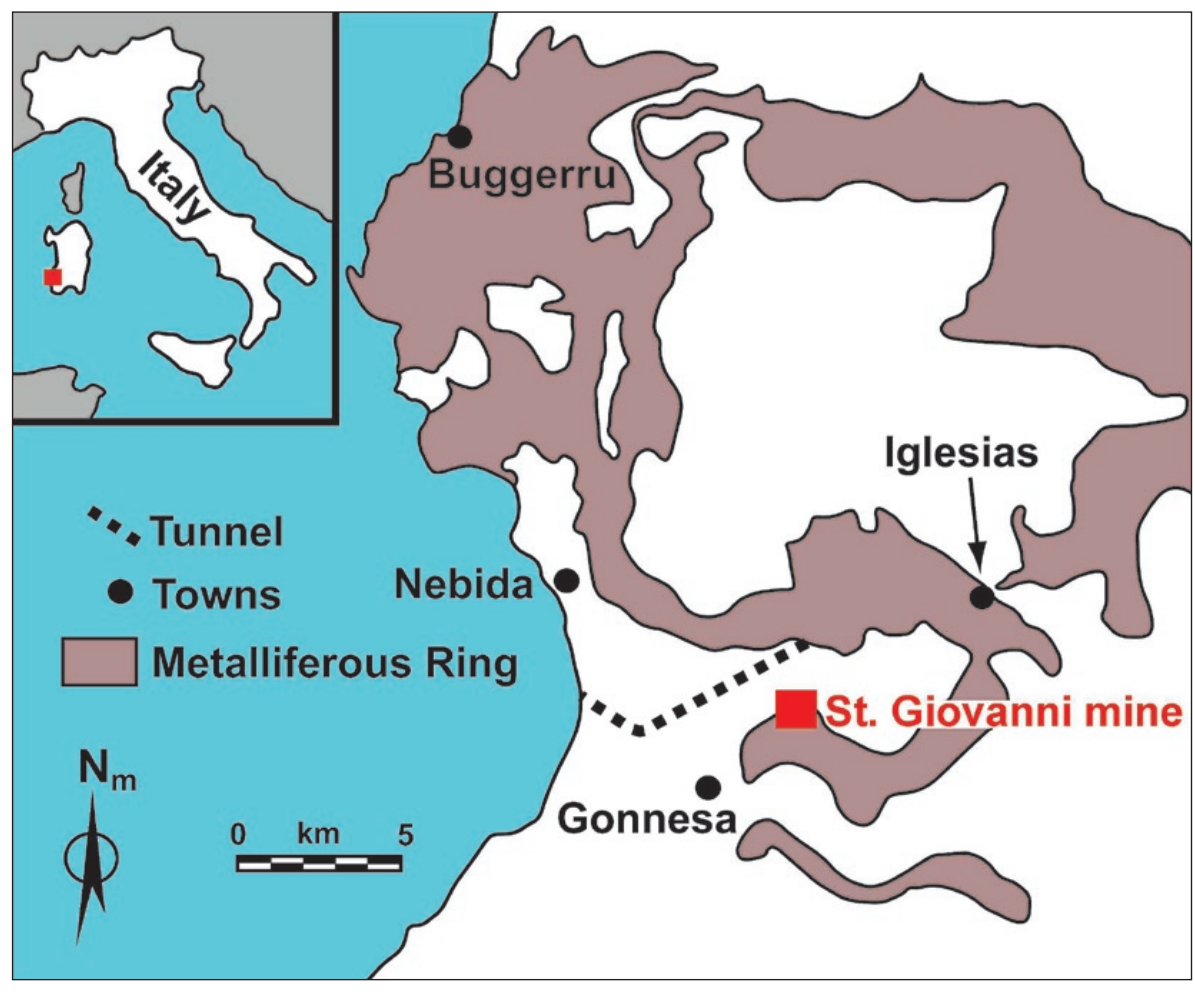

the UNESCO World Heritage List (De Waele et al. 2003). Meanwhile Santa Barbara cave was transformed into a real tourist cave since 2002 (Sarritzu 2005).

Since its discovery the cave was studied mainly for its morphological and mineralogical peculiarities (Rossetti \& Zucchini 1957). Such first work enclosed also an absolutely schematic cavity map (Fig. 3).

Fig. 2: Location map for San Giovanni mine, Iglesiente, Italy. 


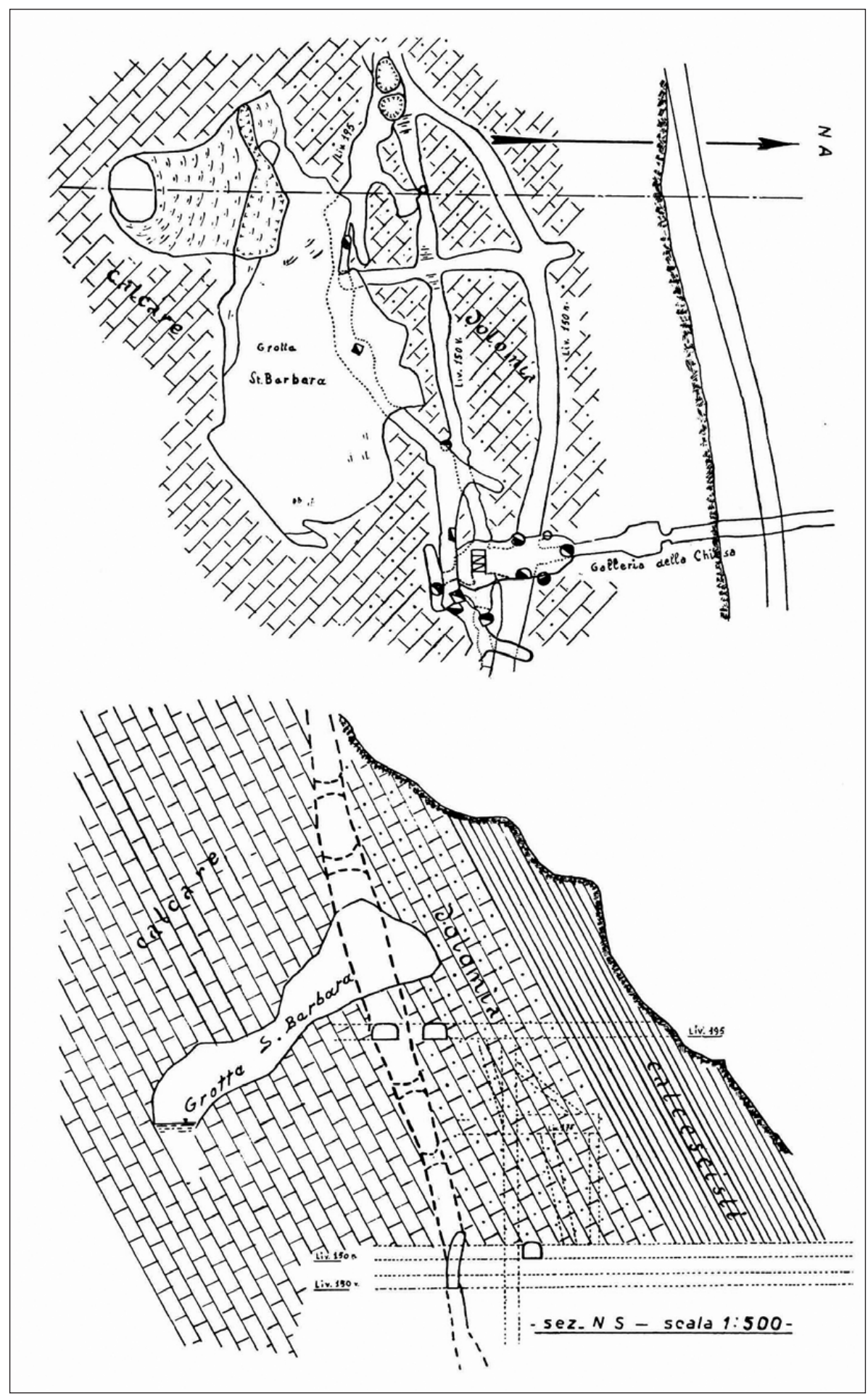

Fig. 3: The first map of Santa Barbara cave (after Rossetti \& Zucchini, 1957).

within the same project, a new large cave was discovered 150 meters below Santa Barbara. According to its position, right below and almost aligned, it was supposed to be part of the same system (Fabbri \& Forti 1986). The exploration and survey of this cave, named Santa Barbara 2, were completed only in 2005 (Badino \& Messina 2005). It was clear that once the two caves were connected in a single karst system which was recently disconnected due to the deposition of a thick flowstone in the last period of their evolution (Forti et al. 2005).

Finally in 2009 a new exploration started in Santa Barbara and discovered an upward branch longer than 40 meters, the exploration of which is still in progress.

In the last 20 years Santa Barbara karst system has been the subject of scientific researches related to its physical sediments (Bini et al. 1988), speleogenesis (De Waele et al. 2001), speleothems and cave minerals (Forti et al. 2005), microclimate (Chiesi 2005), speleobiology (Negri et al. 2005),

Over 25 years later, within an European project on the hydrology of the Iglesiente area (Forti \& Perna 1982), there was the first real speleological exploration of the cave. Some small branches going downwards and upwards were discovered, and the first relatively accurate survey was plotted (Fabbri \& Forti 1981) (Fig. 4). In 1985, its hyperkarstic corrosion types (De Waele \& Forti 2006) and at last paleoclimatic reconstructions (Pagliara et al. 2008, 2010).

The more the scientific studies of the karst system were proceeding, the more the inadequacy of the available topography became evident. Consequently, in 2008 


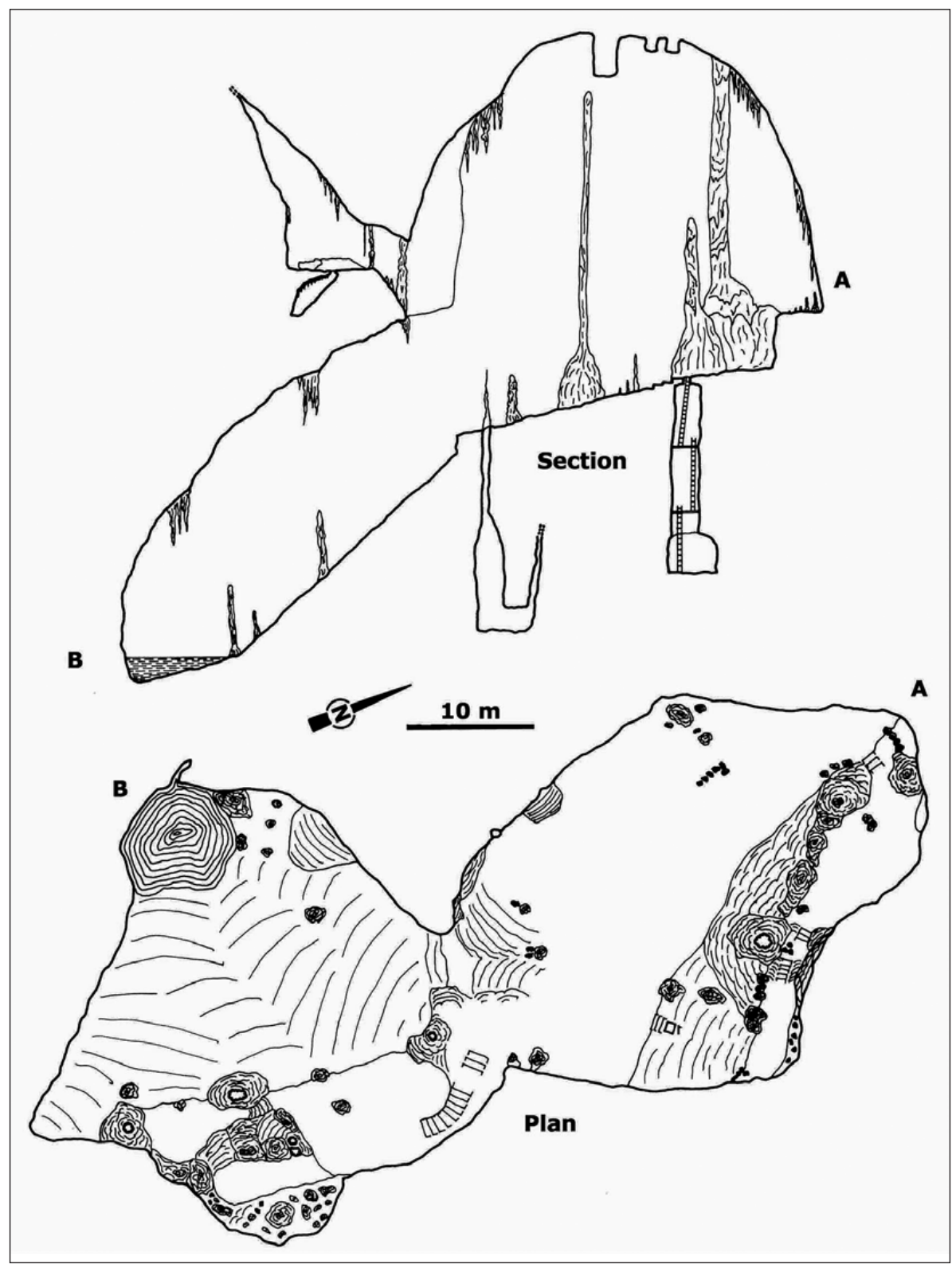

Fig. 4: The map of Santa Barbara by M. Fabbri (after Forti \& Perna, 1982).

lola 1989; Carmignani et al. 2001), so for further treatments it is advisable to refer to bibliography. The area consists of Palaeozoic sediments settled from the Early Cambrian to the Early Ordovician at first. Sedimentation then continued from the Late Ordovician to the Late Pennsylvanian. From bottom to top the deposit sequence is: the Santa Barbara formation (a grey dolostone with evident sedimentary structures) followed by the San Giovanni formation (a very karstified white-greyish limestone) on which the "calcare ceroide" (an anchi-methamorphic massive darker limestone) rests. On top of the carbonate sequence there are nodular limestones and phyllites of the Cabitza formation (Middle Cambrian-Early Ordovician), which are the core of the Iglesias syncline. The structural setting of the area is the consequence of four consecutive deforming events: the Sardinian phase, before Ordovician trans-

a three-dimensional survey with laser scanning technology was carried out.

The present paper, after a short geological and speleogenetic introduction on the karst system and a historical note about San Giovanni mine (one of the most important for the lead and zinc mining activity in the Iglesiente area), illustrates in detail the used technologies and the obtained results. Finally, the future opportunities of laser scanner techniques in caves are discussed.

Mount San Giovanni is part of the Iglesias syncline, which in the past was commonly called "Iglesiente metalliferous ring”. The geological-stratigraphic structural and hydrogeological setting of the area has already been studied in the utmost detail (Civita et al. 1983; Pil- gression, and the following three Variscan orogenetic phases. Finally, the Alpine orogenesis caused minimal deformations only. Santa Barbara karst system grew exactly in contact between the "calcari ceroidi" and the Santa Barbara formation. Such system subdivides into two great caves, now not connected, but developed in the same vertical plane: Santa Barbara cave (from 180 to 227 meters a.s.l.) and Santa Barbara 2 cave (from 52 to 145 meters a.s.l.) (Fig. 5). Such karst system is one of the oldest in the world and it has been involved in nine karst cycles (Forti et al. 2005), the first of which was in the Cambrian during a short emersion phase (Bechstadt \& Boni 1996). Later, from 500,000 to $250,000 \mathrm{BP}$, gravitative speleothems started to grow in the system. Today, 
they are still partly active and their continuous growth caused the splitting of the system into two completely separated caves.

The history of San Giovanni mine started a long time ago when the ancient inhabitants discovered abundance of metals in the calcareous beds: lead and silver above all. The mining activity massively involved such area for centuries with a great increase in the Pisan age, which is evidenced by the hundreds of excavations of that period. Mining activity slowly and gradually declined under Aragonese domination. Such decline ended only in $18^{\text {th }}$ century, when there was a real mining industry explosion, due to important law impulses also. San Giovanni mine was one of the main protagonists of the feverish mining activities of that time. The richness of deposits and the need to intensively exploit them caused such quick technological developments that (it can be surely said) San Giovanni was one of the most advanced mines in the world, both for excavation techniques and working processes afterwards. Mining activities declined, and in 1998 San Giovanni mine was the last of the great Sardinian mines to cease its production. The total metal (lead and zinc) production of the mine in over 130 years of modern industry history is estimated at more than one million tons. Mining works involved nearly exclusively the carbonate sequences and laid out excavations totalling more than 100 kilometres long galleries, laying out over 2 kilometres along E-W direction and over 700 meters along N-S direction. The works vertically involved a depth of rock departing from the surface (about 400 meters a.s.l.) to 250 meters below sea level. Even if destructive and destructuring, it was a much more successful "exploration" than the regular speleological researches, in fact more than 70 natural cavities were discovered.

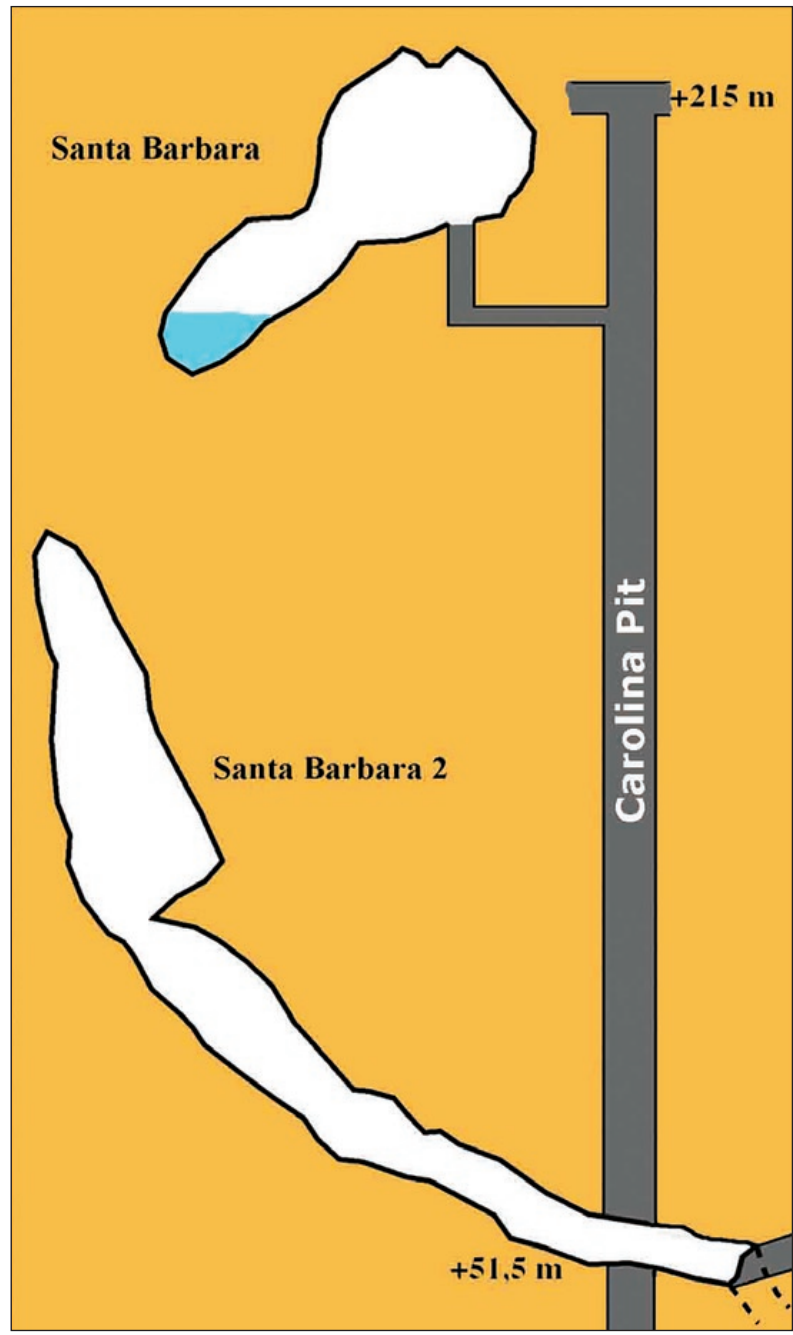

Fig. 5: Sketch of Santa Barbara karst system (after Forti et al., 2005 modified).

\section{METHODS}

In December 2008 the survey by three-dimensional laser scanning of a part of San Giovanni mine complex was performed (Canevese et al. 2009). The work was aiming at giving a uniform and final (according to the present-day knowledge of Santa Barbara and Santa Barbara 2 caves) form to the three speleological surveys above mentioned, which were carried out in different times from 1956 to 2005, during consecutive exploration phases of the karst system.

Laser scanning survey instruments systematically acquire $\mathrm{x}, \mathrm{y}, \mathrm{z}$ spatial coordinates of surveyed surfaces, as high density "point clouds", by analysing the inbound signal of the emitted laser pulse. In addition to spatial coordinates, for each point laser scanner acquires the intensity of the pulse reflected back, according to the material characteristics of the surfaces. Moreover, it allows to associate each surveyed point with a RGB colour value, thanks to an associated camera.

Terrestrial laser scanners available on the market are different in functioning principles and inbound signal reception and processing systems (time-of-flight, phase shift, triangulation), range (maximum ranges vary from few dozen centimetres up to some thousand meters), accuracy and precision. According to the peculiarities of the object/area to be surveyed, their extension and distance as well as working conditions, the choice of a 
laser scanner has to be evaluated in relation to its technical specifications: accuracy, field of view, range, measurement speed, pulse wavelength (which is influenced by reflectivity, humidity on surfaces and environmental factors), portable format (weight, dimensions, toughness), power supply, user interface, data storage and transfer, peak operating temperature and humidity levels.

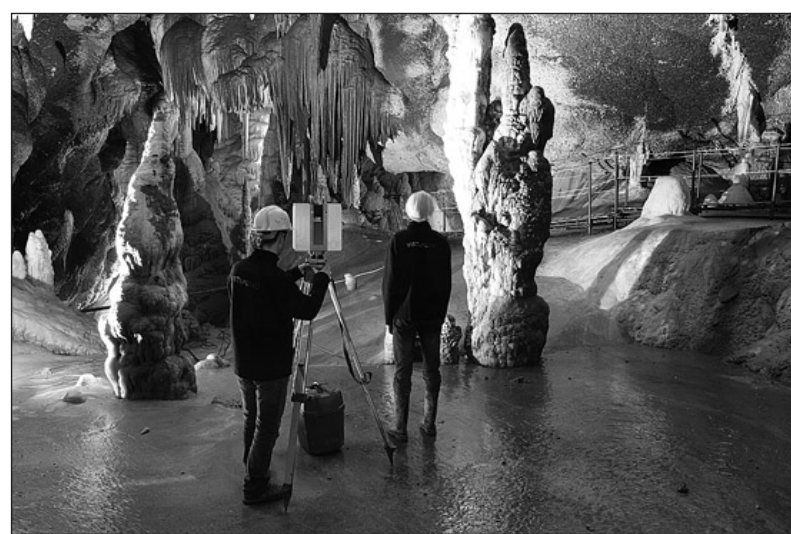

Fig. 6: Laser scanning phase in Santa Barbara cave.

A phase shift technology-based laser scanner was used to survey the subterranean spaces of San Giovanni mine (Fig. 6). This scanner measures the distance of an object "comparing" pulses of different wavelengths reflected back to the instrument. The laser scanner used outside is a time of flight technology-based instrument that measures the distance of the surveyed object by timing the round trip times of the emitted light pulses. It is a long measurement range laser scanner with a limited vertical scanning range $\left(\mathrm{H} 360^{\circ}-\mathrm{V} 80^{\circ}\right)$, suitable for surveying outside over large surfaces. On the contrary, the laser scanner chosen for the underground parts has a shorter measurement range (suitable for smaller spaces), an almost spherical field of view ( $\left.\mathrm{H} 360^{\circ}-\mathrm{V} 310^{\circ}\right)$, which is particularly suitable to survey inside closed spaces (such as caves and tunnels), and a high points per second measurement speed. Moreover, such laser scanner has more compact size and lower weight, so it is more functional to transport and manage (Tab. 1).

The complexity of the subject required an acquisition plan. The survey concerned the outside areas close to the mine entrances, access and connection galleries, tourist areas (magazine of explosives, extraction areas etc.), Santa Barbara and Santa Barbara 2 caves (which have entrance levels with different position and elevation). Especially for the subterranean areas, the acquisition plan was useful to locate, according to the survey object, the best positions of the scanner stations in relation to the accessibility of spaces and in order not to interfere with the flow of tourists. The preliminary study of the scanning acquisition plan allowed to reduce "shadows" in the scans and define the most appropriate scanning angles in order to obtain scans with a uniform resolution (by setting the average distance between scanner stations and surfaces to acquire as well as the scanning point grid density) and good overlapping area.

For the whole laser scanning survey 77 reference targets were placed (in significant and visible points) and surveyed with total station for the following operation of georeferencing and registration (union) of the point clouds obtained from the scans. Together with the laser scanning survey, topographic works were executed to establish three open traverses (with 22 control points and overall length of 2 kilometres) in order to georefer the levels and execute a planimetric and altimetric connection between the levels of:

- (main traverse) Santa Barbara 2 cave (elevation $+50.50 \mathrm{~m})$, its entrance gallery $(+140.33 \mathrm{~m})$, outside area, entrance gallery of tourist train $(+154.75 \mathrm{~m})$, magazine of explosives $(+158.50 \mathrm{~m})$;

- (secondary traverse no. 1) arrival gallery of tourist lift $(+192.53 \mathrm{~m})$;

Tab. 1: Technical specifications of the laser scanners used to survey San Giovanni mine.

\begin{tabular}{lll}
\hline Laser scanner model & $\begin{array}{l}\text { LEICA HDS6100 } \\
\text { (Subterranean Survey) }\end{array}$ & $\begin{array}{l}\text { RIEGL LMS- Z420i } \\
\text { (Outside Survey) }\end{array}$ \\
\hline Range & $1 \mathrm{~m}-79 \mathrm{~m}$ & $2 \mathrm{~m}-1,000 \mathrm{~m}$ \\
\hline Measurement rate & 500,000 points/second & $8,000-11,000$ points/second \\
\hline Accuracy & $\pm 1 \mathrm{~mm}$ at $25 \mathrm{~m}$ & $\pm 10 \mathrm{~mm}$ at $50 \mathrm{~m}$ \\
\hline Horizontal field of view & $\pm 2.4 \mathrm{~mm}$ at $50 \mathrm{~m}$ & $360^{\circ}$ \\
\hline Vertical field of view & $360^{\circ}$ & $80^{\circ}$ \\
\hline Weight & $310^{\circ}$ & $16 \mathrm{~kg}$ \\
\hline Dimensions & $14 \mathrm{~kg}$ & $463 \times 210 \mathrm{~mm}(\mathrm{LxD})$ \\
\hline Operating conditions & $244 \times 190 \times 351.5 \mathrm{~mm}(\mathrm{LxWxH})$ & $0^{\circ}-40^{\circ} \mathrm{C}$ \\
\hline Camera model & $0^{\circ}-40^{\circ} \mathrm{C}$ non-condensing & Canon EOS 10D - 6.5 MPixel \\
\hline
\end{tabular}


- (secondary traverse no. 2) Santa Barbara cave $(+203.50 \mathrm{~m})$.

The vertical connection between the main traverse and the secondary traverse no. 1 was executed by the tourist lift, which is placed inside the Carolina pit. The vertical connection between the main traverse and the secondary traverse no. 2 was performed by the spiral staircase, which is in the access shaft of Santa Barbara cave. The traverses were established in order to survey the reference targets and, in plotting phase, to integrate the official regional cartography with the location of the surveyed area. The work times for control points establishing, target placing, outside and underground surveying as well as the "size" of the data acquired by laser scanners and external cameras are summarized in Tab. 2.

Tab. 2: "Quantities" acquired by laser scanners and cameras in the complex of San Giovanni mine and survey work data.

\begin{tabular}{ll}
\hline Scans & 46 \\
\hline Acquired points & about 8,000,000,000 \\
\hline Acquired 2D images & 322 \\
\hline Acquired laser data amount & $15 \mathrm{~GB}$ \\
\hline Acquired 2D images amount & $4.1 \mathrm{~GB}$ (raw+jpg) \\
\hline Work times & 8 daily hours in 4 working days \\
\hline Staff & 4 technicians \\
\hline
\end{tabular}

The point clouds acquired by scanning from different stations, once unified through renowned reference points and georeferred to a single reference system by an appropriate software, reconstruct the three-dimensional shape of the surveyed object or area. The final result of the scans and their post-processing is a global point

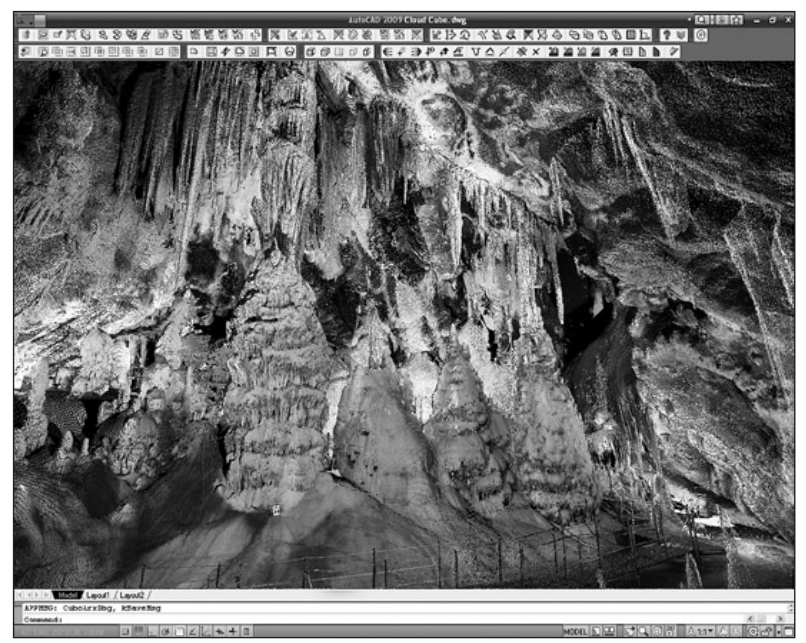

Fig. 7: A detail of the point cloud of Santa Barbara cave visualized on AutoCAD platform with Virtualgeo's CloudCUBE software (the location of the visualized detail is highlighted in Fig. 9). cloud, which is a metrically accurate three-dimensional point model of the surveyed object containing also chromatic information. This latter information, which can be grey scale reflectance data or RGB values, visually helps the final users to interpret the surveyed object and extract geometrical data from the point model.

The post-processing and representation of data followed the measurement phase. They are crucial stages to optimize laser scanner potentialities, therefore the support of a dedicated software is essential for the suitability of the acquired information. Thids is fundamental for the data and their processing and also for the production of an effective productive three-dimensional model, which can satisfy the purposes of the survey and also the potential objectives, not yet foreseen.

The post-processing of the data acquired in San Giovanni mine was performed with Cyclone software. It meant registering and then carefully cleaning and filtering point clouds to remove "noise" and non significant points (Fig. 7). The following processing phase of the acquired information consisted of three-dimensional modelling the surveyed surfaces with CloudCUBE, software on AutoCAD' platform developed by Virtualgeo with a Russian research centre. The software provided the tools to treat the millions of points acquired, manage them in optimized way and elaborate a "smart" three-dimensional model, which is accurate according to

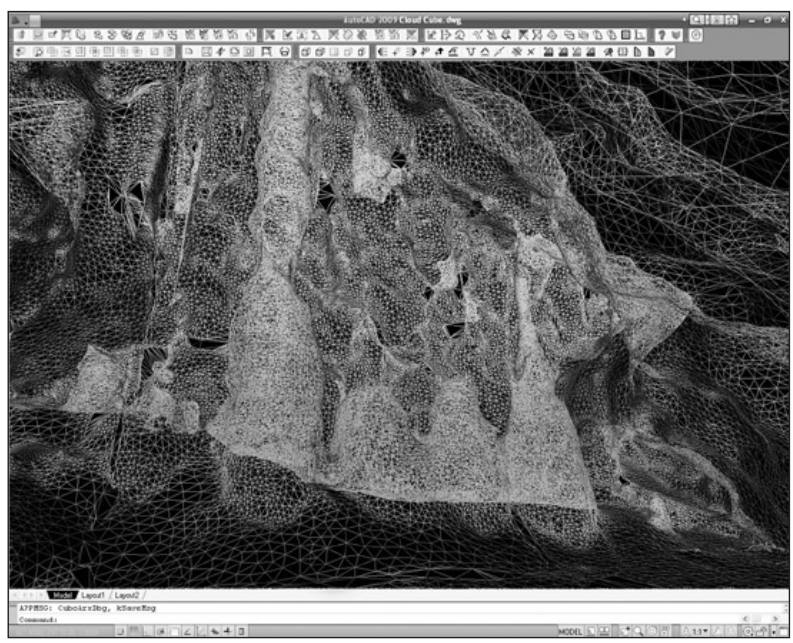

Fig. 8: The same detail of the 3D model elaborated from the point cloud with CloudCUBE 3D modelling functionalities (the footway wasn't modelled). 
real shapes (both metrically and morphologically) and innovative regarding the immediate and potential uses of the survey. The caves, speleothems and galleries were modelled with the most suitable among the techniques $(2.5 \mathrm{D}$ and $3 \mathrm{D}$ triangular grid meshes, quadrangular "surfaces", "region" entities) for modelling their dimensions and complex uneven morphologies: the construction of 3D triangular meshes was carried out directly on point clouds by an automatic technique (Fig. 8). In the process of vertex joining the $2.5 \mathrm{D}$ triangular mesh takes into account the $\mathrm{x}, \mathrm{y}$ coordinates only, whereas the $3 \mathrm{D}$ mesh considers all the three $\mathrm{x}, \mathrm{y}, \mathrm{z}$ coordinates. The model of San Giovanni mine was "segmented", i.e. divided into parts associated with different layers, which are visually identified with different colours (of the various materials and concretions). It can be "re-segmented" according to specialised requirements and customized standards (related to structural elements, chemical composition, morphological characteristics, deposit sequences, etc.). The model segmentation helps the user in interpreting the object of the survey and, in a long-term perspective, allows to evaluate possible natural changes in the cave.

\section{RESULTS}

Point clouds acquired by laser scanning are in themselves a complete database of three-dimensional and qualitative data related to the present conditions of San Giovanni mine. Such information is superior, in quantity and reliability, to the data obtained from traditional topographic surveys or on site inspections. Point clouds allow to visualize the object morphology (colours or grey scale make such reading phase easier) and extract dimensional (linear and angular) data.

The total digital model of San Giovanni mine, obtained by elaborating the point clouds, is a complete very high precision three-dimensional database. A series of graphic representations (plans with elevation levels and sections with orthophotomaps) were elaborated from the model. They were sufficient to provide a clear graphic de-

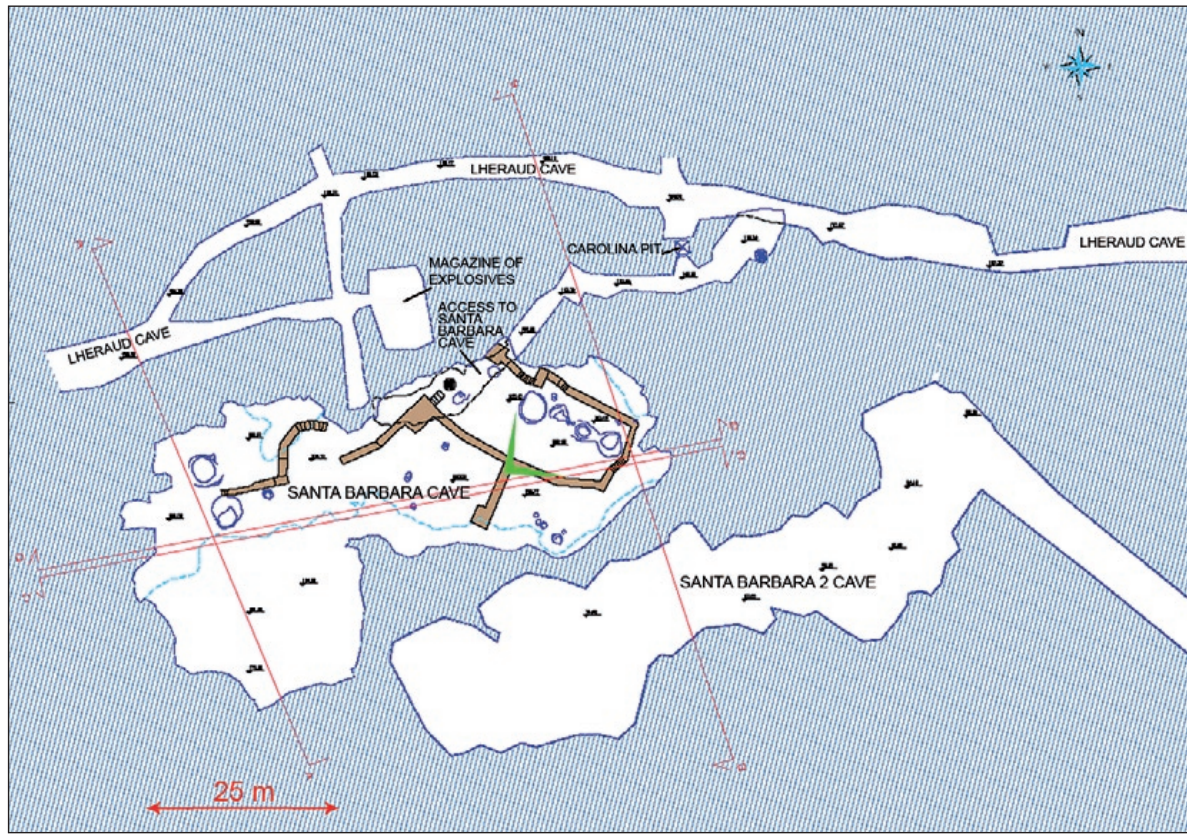

scription of the surveyed part of San Giovanni complex (examples of graphic representations are in Fig.9 and Fig. 10). It is possible to obtain from the three-dimensional model unlimited representations of any type, with any scale, and plot plans at any elevation level and vertical sections along any section plan, without additional surveys in site to complete missing data.

On the contrary of the previous outline surveys, the San Giovanni three-dimensional model allowed to define with the utmost precision the mutual position of Santa Barbara and Santa Barbara 2 caves as well as the position of caves and galleries in the mountain, in which they open. The model also allowed to define in detail the geometry of the surveyed objects, revealing their real proportions in comparison with the mountain itself. The digital model allows to extract any type of dimensional information (linear and angular) and compute areas and volumes.

Fig. 9: Overall plan with elevation levels of the surveyed parts of San Giovanni mine. The green visual angle shows the cave portion visible in Fig. 7 and Fig. 8. 


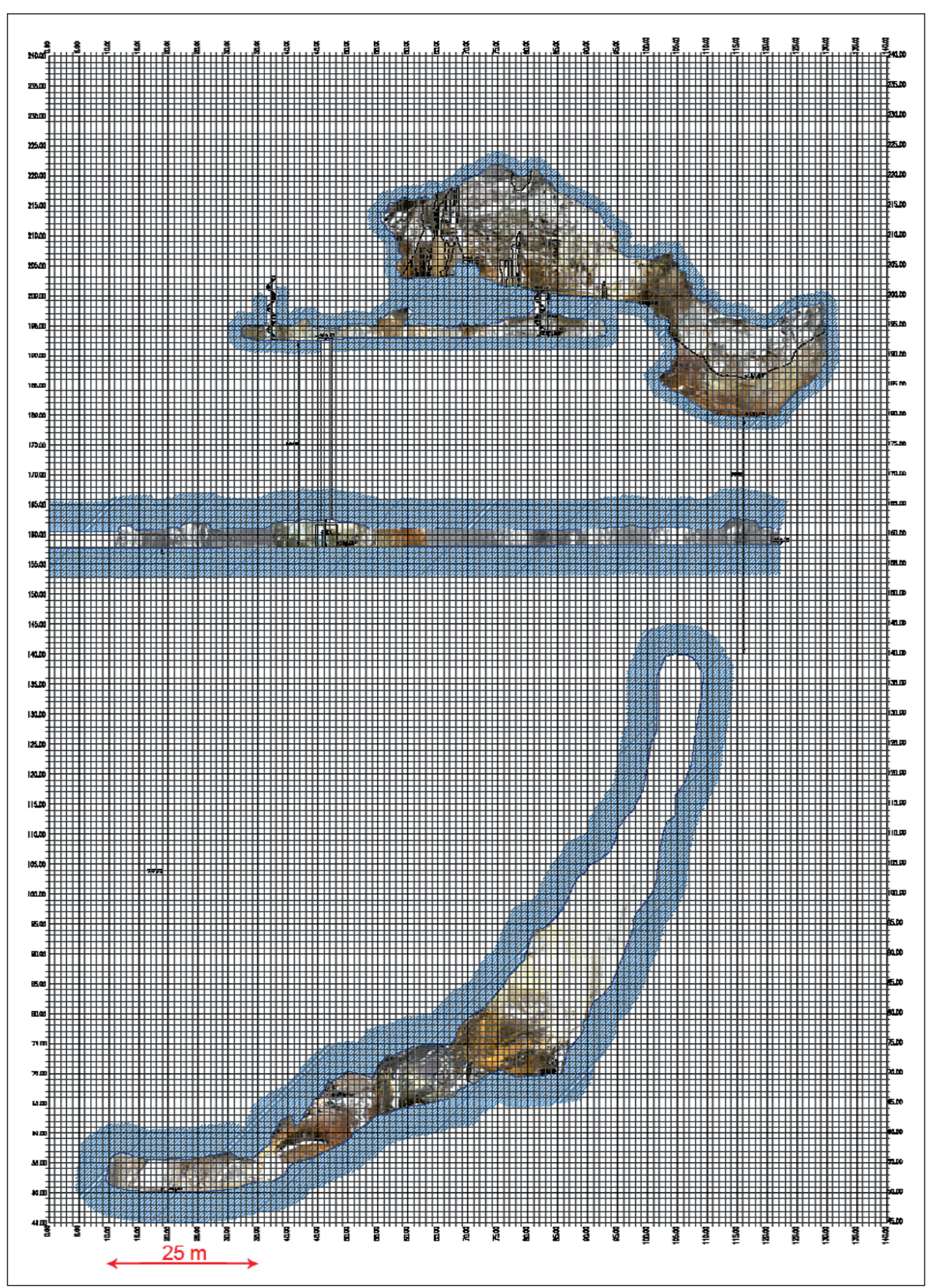

Fig. 10: A vertical section of San Giovanni mine with point cloud orthophotomaps and reference metric grid.

\section{DISCUSSION}

Topographical documentation is an essential phase for the management and preservation activities concerning the underground environmental heritage. Such activities, in fact, require a thorough detailed knowledge of their subjects. The aim of a speleological topographic survey is producing maps that, together with descriptive and iconographic information, can construct a reliable precise and complete database for speleologists, scientists, agencies administering territory and environmental safeguard, authorities managing caves, etc. Moreover, maps should be an appropriate basis on which all the activities of basic research and research for practical applications about caves can be found. A hypogean topographic survey has to be independent of topographer's discretion and gather the greatest amount of data according to the significance and usability that such information can have 
for the various users (scientific, institutional etc.) in different times.

Cave surveying poses operative and logistic problems due to complexity, extension and environment of the cavities subject of study. These elements make a precise topographical survey difficult by using traditional methods. Traditional speleological topographic survey implies an orderly team work with technologically not sophisticated instruments. It is a not very precise survey, easily affected by data acquisition errors due to many factors, among which the environmental conditions are particularly important. Other factors are the technicians' attitude and experience and the instruments and procedures in use.

Laser scanning can be an alternative to traditional speleological topographic surveys (Pucci \& Marambio 2009). Its application, in fact, has grown much in the last ten years, covering many applications thanks to its versatility: in environmental (Sheppard 2004), industry and piping system fields, in infrastructure engineering, archaeology (Fryer et al. 2005; González-Aguilera et al. 2009; Hanke et al. 2009), architecture, etc. Laser scanning enters in different kinds of work processes providing data of primary importance, which can be integrated with data, obtained with other instrumental survey techniques, to interpret complex systems and relationships between their components. Concerning geology and engineering geology, literature produced in the last years proves the potentialities of laser scanning techniques for geomorphic studies, for monitoring and supervising (quantitative control) both in managing natural events (for routine and/or after exceptional events) and managing activities of territory "transformation" (geo-resources, infrastructure works, etc.) (Alba et al. 2009; Clerici et al. 2005).

The fast rate measurement, the data completeness, accuracy and quality, the non-contact with the surveyed surfaces (essential not to affect their integrity) and the adaptability of use allow laser scanning to perform precision surveys (Caprioli et al. 2003) also in front of large surfaces and great morphological complexity (i.e., a great amount of data to acquire and manage) keeping working continuity in site. It promises high survey productivity even in difficult or dangerous working conditions (operative, environmental, logistic, etc.) (Canevese et al. 2008). Just as there are access difficulties, danger of landslides, rock detachments, etc., laser scanning is better than traditional survey systems, as it allows remote work in safe conditions. Moreover, laser scanning is economically advantageous, as rapidity and automation assure time saving in acquisition phase, also with a single technician.

Point clouds are a complete database both of quantitative and qualitative data of the surveyed object. Modelling such clouds with a dedicated software allows to obtain a total three-dimensional model of high detail, even increased by the technical segmentation process, of the object. Moreover, it is possible to study the dynamics of evolving phenomena (e.g., rock detachments) by "superimposing" digital models obtained in periodic surveys. Only such an accurate topographical basis, corresponding to the complete morphology of the surveyed object, allows significant qualitative analyses and reliable computations (in multitemporal modality also) and so affords real advantages both to research activities and all territory knowledge and managing processes. One of these advantages is plotting the surveyed object obtaining from the model the areas of the segmented elements (e.g., related to deposit sequences existing in the cave) and unlimited representations of any type, which can be reproduced with any scale, without risking lack of data and without going back to the site to check measurement discrepancies (disclosed in the representation phase) or to complete missing data.

The digital model and graphic representations can be used not only to study the present conditions of the subject of interest, but also to verify hypothesis or draw up projects (e.g. to preserve caves or improve access and safety of caves provided with tourist facilities etc.).

The laser scanner peculiarities (measurement speed, accuracy, non-contact with objects, applicative versatility), the completeness and quality of acquired data, the possibility to represent data and extract customized information from them (according to the survey users' needs), make laser scanning technique an essential support for an advanced topographical approach, which is based also on a innovative survey data post-processing method to produce "smart" three-dimensional models. Such knowledge is the basic premise of all decision-making procedures as well as of activities for planning and managing territory, in its underground dimension also. 


\section{CONCLUSIONS}

The morphological knowledge of territory, which takes shape into thematic cartography and databases, is of primary importance for the safeguard of the environment and its resources as well as for public security.

The speleological topographic survey and digital reconstruction of Santa Barbara karst system in San Giovanni mine complex (Iglesias, Italy) have shown in practice that laser scanning technique and the used three-dimensional modelling techniques offer a solution for the morphological knowledge of the territory, which can be applied to subterranean contexts also, where a remarkable morphologic complexity and a great amount of data has to be managed even in difficult operative conditions. Laser scanning allows to acquire the geometry of hypogean cavities in a precise comprehensive way, limiting risks related to lack or inadequacy of data. It delivers an objective survey and final users can select the significant and useful data by themselves.

The remote study (without time and space restrictions) of the subject of interest from many points of view (geomorphic, stratigraphic, palaeontologic, etc.) (Chandelier \& Roche 2009) by means of high precision detailed morphometric databases is a particularly interesting prospect for the multidisciplinary research concerning caves.

Laser scanning could be used on a wide scale for the collection of data related to natural caves and areas of speleological importance to construct the regional cave cadastres, to obtain archives of homogeneous data in precision, completeness, quantitative and qualitative characteristics.
Furthermore, data acquired by laser scanning can be used not only for technical-operative or research purposes, but also, once they are properly re-elaborated, for educational and public dissemination purposes. In fact, from the digital model it is possible to obtain "products" for scientific dissemination. Concerning the subject of the present paper, for instance, a scale model of Santa Barbara cave was produced by rapid prototyping threedimensional printer (Fig. 11) as well as a video with the stereoscopic animation of the point cloud of San Giovanni mine, which is an additional tool (dedicated to the disabled also) to virtually "enter" the beauty of such an exceptional geological site.

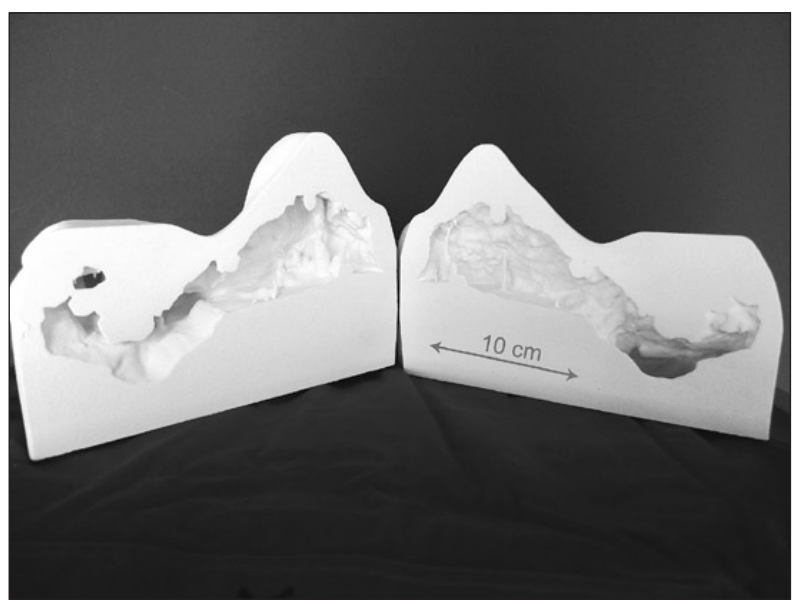

Fig. 11: The scale plastic model of Santa Barbara cave produced with rapid prototyping $3 D$ printer.

\section{ACKNOWLEDGEMENTS}

Thanks are due to the Geo-mining Historical and Environmental Park of Sardinia that includes the San Giovanni mine complex. The access to Santa Barbara cave was possible thanks to the collaboration of IGEA S.p.A., which is the responsible board for the tourist managing of the cave, and help of Sardinian Speleological Federation, which is the association coordinating the activities of the local speleological groups, development of speleological researches and safeguard of speleological heritage in Sardinia.
Thanks are due to Giovanni Badino for sharing with the authors the results of the new exploration (started in 2009) in Santa Barbara cave.

Laser scanning survey was carried out by Virtualgeo s.r.l., Italian company working in the fields of geomatics and software development since 1994 and supplying services for the study and advancement of cultural and environmental heritage, in collaboration with Leica Geosystems S.p.A., which is the Italian branch of Leica Geosystems AG multinational company. 


\section{REFERENCES}

Alba, M., Roncoroni, F. \& M. Scaioni, 2009: Application of TLS for Change Detection in Rock Faces.Proceedings of the ISPRS Workshop "Laserscanning 2009”, $1^{\text {st }}-2^{\text {nd }}$ September 2009,Paris (France), International Archives of the Photogrammetry, Remote Sensing and Spatial Information Science, 38, part 3/W8, 99-104.

Badino, G. \& M. Messina, 2005: Lesplorazione della grotta di Santa Barbara 2 [The Exploration of Santa Barbara 2 Cave].- Memorie dell'Istituto Italiano di Speleologia, 17, 93-98.

Bechstadt, T. \& M. Boni, 1996: Sedimentological, stratigraphical and ore deposits field guide of the autochtonous Cambro - Ordovician of Southwestern Sardinia.- Memorie descrittive della Carta Geologica d'Italia, 48, 1-390.

Bini, A., Cremaschi, M., Forti, P. \& G. Perna, 1988: Paleokarstic fills in Iglesiente (Sardinia, Italy); sedimentary processes and age.- Annales de la Société géologique de Belgique, 111, 149-161.

Canevese, E. P., Tedeschi, R., Forti, P. \& P. Mora, 2008: The Use of Laser Scanning Techniques in Extreme Contexts: the Case of Naica Caves (Chihuahua, Mexico).- Geologia tecnica \& ambientale - Journal of technical \& environmental geology, 2, 19-37.

Canevese, E. P., Tedeschi, R., Forti, P. \& F. Uccelli, 2009: Laser Scanning Use in Cave Contexts: the Cases of Castellana and Santa Barbara (Italy) and Naica (Mexico).- Proceedings of the $15^{\text {th }}$ International Congress of Speleology, Kerrville (USA), 3, 2061-2067.

Caprioli, M., Minchilli, M., Scognamiglio, A. \& G. Strisciuglio, 2003: Using photogrammetry and laser scanning in surveying monumental heritage: le Grotte di Castellana.- Proceedings of the International ISPRS Workshop "Vision Techniques for Digital Architectural and Archaeological Archives", $1^{\text {st }}-3^{\text {rd }}$ July 2003, Ancona (Italy), International Archives of Photogrammetry, Remote Sensing and Spatial Information Sciences, 34, part 5/W12, 107-110.

Carmignani, L., Oggiano, G., Barca, S., Conti, P., Salvadori, I., Eltrudis, A., Funedda, A. \& S. Pasci, 2001: Geologia della Sardegna. Note illustrative della Carta Geologica della Sardegna a scala 1:200.000, Memorie Descrittive della Carta Geologica d'Italia [Geology of Sardinia. Explanatory Notes of the 1/200,000 scale Geological Map of Sardinia, Descriptive Memories of the Geological Map of Italy].- Istituto Poligrafico e Zecca dello Stato, Roma,1-283.
Chandelier, L. \& F. Roche, 2009: Terrestrial Laser Scanning for Paleontologists: the Tautavel Cave.- Proceeding of the XXII CIPA Symposium "Digital Documentation, Interpretation \& Presentation of Cultural Heritage", $11^{\text {th }}-15^{\text {th }}$ October 2009 , Kyoto (Japan).

Chiesi, M., 2005: Il pre-monitoraggio dei parametri ambientali della Grotta di Santa Barbara [The Premonitoring of Environmental Parameters of Santa Barbara Cave].- Memorie dell'Istituto Italiano di Speleologia, 17, 23-34.

Civita, M., Cocozza, T., Forti, P., Perna, G. \& B. Turi, 1983: Idrogeologia del bacino minerario dell'Iglesiente (Sardegna Sud Occidentale) [Hydrogeology of the Mining Field of Iglesiente (South West Sardinia)].- Memorie dell'Istituto Italiano di Speleologia, 2, 139.

Clerici A., Gelmini, M., Ravelli, M., Sgrenzaroli, M. \& G. Vassena, 2005: Applicazioni del Laser Scanner terrestre a temi geologico-tecnici [Terrestrial Laser Scanner Applications on Geological-Technical Subjects].- Giornale di Geologia Applicata, 2, 328-333.

De Waele, J., Di Gregorio, F., Follesa, R. \& G. Piras, 2003: I geositi dell'uomo nel Parco Geominerario Storico Ambientale della Sardegna: alcuni esempi del Sulcis-Iglesiente (Sardegna sud-occidentale) [The Man Geosites in the Geo-mining Historical and Environmental Park of Sardinia: Examples of the SulcisIglesiente (South West Sardinia)].- Proceedings of the National Conference "La Geologia Ambientale: strategie per il nuovo millennio" [The Environmental Geology: Strategies for the New Millennium], $27^{\text {th }}-29^{\text {th }}$ June 2002, Genova (Italy), Geologia dell'Ambiente, 11(1), 192-197.

De Waele, J. \& P. Forti, 2006: A new hypogean karst form: the oxidation vent.- Zeitschrift für Geomorphologie N.F. supplementband, 147, 107-127.

De Waele, J., Forti, P. \& G. Perna, 2001: Hyperkarstic phenomena in the Iglesiente mining district (SWSardinia).- In: Cidu A. (ed.) Water-Rock Interaction 2001, A.A.Balkema Publishers, pp. 619-622, Lisse.

Fabbri, M. \& P. Forti, 1981: Esplorazioni nell'Iglesiente [Explorations in the Iglesiente Area].- Sottoterra, 59, 31-35.

Fabbri, M. \& P. Forti, 1986: Recenti esplorazioni nelle miniere dell'Iglesiente (Sardegna Sud Occidentale) [Recent Explorations in the Mines of Iglesiente (South West Sardinia)].- Sottoterra, 74, 1-9. 
Forti, P., Pagliara, A., Galli, E., Rossi, A., De Waele, J., Naseddu, A. \& S. Papinuto, 2005: Studio morfologico e mineralogico di dettaglio del concrezionamento del sistema carsico di Santa Barbara (Miniera di San Giovanni, Iglesias) [Detailed Morphological Mineralogical Study on Concretions of Santa Barbara Karst System (San Giovanni Mine, Iglesias)].Memorie dell'Istituto Italiano di Speleologia, 17, 57-68.

Forti, P. \& G. Perna, 1982: Le cavità naturali dell'Iglesiente [The Natural Cavities of Iglesiente Area].- Memorie dell'Istituto Italiano di Speleologia, II (1), 229.

Fryer, J. G., Chandler, J. H. \& S. F. El-Hakim, 2005: Recording and Modelling an Aboriginal Cave Painting: with or without Laser Scanning?- Proceedings of the ISPRS Working Group V/4 Workshop "Virtual Reconstruction and Visualization of Complex Architectures", $22^{\text {nd }}-24^{\text {th }}$ August 2005, Venice (Italy), International Archives of Photogrammetry, Remote Sensing and Spatial Information Sciences, 36, part 5/W17.

González-Aguilera, D., Muñoz-Nieto, A., Gómez-Lahoz, J., Herrero-Pascual, J. \& G. Gutierrez-Alonso, 2009: 3D Digital Surveying and Modelling of Cave Geometry: Application to Paleolithic Rock Art.- Sensors, 9, 1108-1127.

Hanke, K., Hiebel, G., Kovacs, K. \& M. Moser, 2009: Surveying and Geoinformation - Contributions to an Interdisciplinary Special Research Program on the History of Mining Activities.- Proceeding of the XXII CIPA Symposium "Digital Documentation, Interpretation \& Presentation of Cultural Heritage", $11^{\text {th }}-15^{\text {th }}$ October 2009, Kyoto (Japan).

Negri, I., Pellecchia, M. \& P. P. Fanciulli, 2005: I collemboli di alcune grotte di miniera e cavità ipogee dell'Iglesiente [The Collembola of Some Mine Caves and Hypogean Cavities of the Iglesiente Area].- Memorie dell'Istituto Italiano di Speleologia, 17, 99-104.

Pagliara, A., Forti, P., Rossi, A. \& Y. Y. Shopov, 2008: Studio delle fluttuazioni climatiche quaternarie dell'Iglesiente mediante l'analisi di speleotemi della Grotta di Santa Barbara (Iglesias, CA) [Study on Quaternary Climatic Fluctuations of Iglesiente by the Analysis of the Santa Barbara Cave Speleothems].- Memorie dell'Istituto Italiano di Speleologia, 21, 167-177.
Pagliara, A., De Waele, J., Forti, P., Galli, E. \& A. Rossi, 2010: Speleothems and speleogenesis of the hypogenic Santa Barbara Cave System (South-West Sardinia, Italy).- Acta Carsologica 39(3), 551-564.

Pillola, G. L., 1989: Trilobites du Cambrien inférieur du SW de la Sardaigne, Italie.- Paleontographica Italica, 78, 1-174.

Pucci, B. \& A. Marambio, 2009: Olerdola's cave, Catalonia: a Virtual Reality Reconstruction from Terrestrial Laser Scanner and GIS Data.- Proceedings of the International ISPRS Workshop "Virtual Reconstruction and Visualization of Complex Architectures", $25^{\text {th }}-28^{\text {th }}$ February 2009, Trento (Italy), International Archives of Photogrammetry, Remote Sensing and Spatial Information Sciences, 38, part 5/W1.

Rossetti, V. \& A. Zucchini, 1957: Baritina della Grotta di Santa Barbara [Baryte of the Santa Barbara Cave].Rendiconti del Seminario della Facoltà di Scienze Università di Cagliari, 26 (3-4), 240-255.

Sarritzu, R., 2005: La grotta di Santa Barbara da gioiello minerario a risorsa del territorio [Santa Barbara Cave from Mining Jewel to Territory Resource].Memorie dell'Istituto Italiano di Speleologia, 17, 155-160.

Sheppard, S., 2004: Laser-Scanning for Landscape Planning: Implications for Policy and Practice from an End-User's Perspective.- Proceedings of the ISPRS Working Group VIII/2 "Laser-Scanners for Forest and Landscape Assessment", $3^{\text {rd }}-6^{\text {th }}$ October 2004, Freiburg (Germany), International Archives of Photogrammetry, Remote Sensing and Spatial Information Sciences, 36, part 8/W2, 237-246. 